\title{
How the Organizational Context Impacts Volunteers: A Differentiated Perspective on Self-determined Motivation
}

\author{
Susan van Schie - Stefan T. Güntert • \\ Jeannette Oostlander - Theo Wehner
}

Published online: 8 August 2014

(C) International Society for Third-Sector Research and The Johns Hopkins University 2014

\begin{abstract}
The aim of the present study was to examine how the organizational context of a non-profit organization (NPO) influences the motivation and work behaviors of volunteers. We hypothesized that the organizational context-operationalized by the motivational potential of the tasks, autonomy supportiveness of the supervisor, and value congruence between volunteer and NPO - can benefit or thwart self-determined motivation, which in turn predicts work engagement and organizational citizenship behaviors (OCB). In particular, the innovative aim of the study was to differentiate between general and organization-focused self-determined motivation (general and organization-focused SDM). Structural Equation Modeling revealed a distinction based on data from 2,222 volunteers: general SDM was related to the motivational potential of the task, whereas value congruence accounted for organization-focused SDM. Autonomy supportiveness of the supervisor similarly influenced both foci. Furthermore, general SDM enhanced work engagement, whereas OCB was solely linked to organization-focused SDM.
\end{abstract}

Résumé Ce travail de recherche améliore notre compréhension des fondations émergentes d'entreprise et privées en Inde, en adoptant le point de vue de leurs fondateurs : la nouvelle génération de dirigeants d'entreprise indiens très fortunés. Basé sur plus de quarante-cinq entretiens et s'inspirant de la littérature existante, il explore l'environnement de ces personnes, leur position unique d' « hyperagents », ainsi que le contexte indien qui modèle leurs fondations. Nos résultats suggèrent que ces philanthropes préfèrent les modèles de fondations opérationnels ainsi que les secteurs «sûrs » en termes politiques et sociaux; ils transfèrent les tendances d'entreprise, poursuivent l'objectif d'un changement social en prenant un rôle de guide ou de catalyseur, et ont une préférence pour le contrôle au détriment de la

S. van Schie $(\bowtie) \cdot$ S. T. Güntert $\cdot$ J. Oostlander $\cdot$ T. Wehner

Department of Management, Technology, and Economics, ETH Zürich, Weinbergstrasse 56/58,

WEV K 514, 8092 Zurich, Switzerland

e-mail: svanschie@ethz.ch 
coordination des acteurs. Ces approches sont logiques étant donné le contexte, mais elles constituent plus un pas vers davantage de philanthropie de la part des personnes fortunées du pays qu'un objectif idéal. Ce travail pourra s'avérer intéressant pour qui souhaite entamer une collaboration avec les fondations et les philanthropes indiens. De plus, étant donné le peu de recherche existant sur la philanthropie indienne, il contribue au développement des théories spécifiques à l'Inde.

Zusammenfassung Diese Studie verhilft uns zu einem Verständnis der neu entstehenden Unternehmens- und Privatstiftungen in Indien aus der Perspektive ihrer Gründer, nämlich Indiens neue Generation hochvermögender Unternehmer. Beruhend auf mehr als 45 Befragungen und aufbauend auf der vorhandenen Literatur untersucht die Studie den Hintergrund dieser Personen, ihre einzigartige Position als „Hyper-Verteter“und die indischen Rahmenbedingungen, unter denen sich ihre Stiftungen gestalten. Die Ergebnisse weisen darauf hin, dass diese Philanthropen operationelle Stiftungsmodelle, politisch und gesellschaftlich „sichere“Bereiche, die Übernahme von Geschäftstendenzen, die Verfolgung einer gesellschaftlichen Veränderung durch eine Antriebs- oder Katalysatorfunktion sowie eine Kontrolle auf Kosten der Koordination zwischen den Akteuren bevorzugen. In dem gegebenen Kontext machen diese Ansätze Sinn; sie sind jedoch nicht das optimale Endziel, sondern eher ein Schritt in Richtung einer Entwicklung der Philanthropie hochvermögender Personen in dem Land. Diese Studie ist für Personen von Interesse, die mit indischen Philanthropen und Stiftungen arbeiten möchten. Zudem ist sie in Anbetracht der nur beschränkt vorhandenen wissenschaftlichen Ausführungen zu indischer Philanthropie ein Beitrag zur Entwicklung Indien-spezifischer Theorien.

Resumen La presente investigación construye nuestra comprensión de las fundaciones hindúes corporativas y privadas emergentes a través de las lentes de sus fundadores - nueva generación de líderes empresariales con patrimonio elevado de la India. Basándose en más de cuarenta y cinco entrevistas y haciendo uso del material existente publicado, la presente investigación explora los antecedentes de estos individuos, su posición única como "hiperagentes", y el contexto hindú que da forma a sus fundaciones. Los hallazgos sugieren que estos filántropos prefieren modelos de fundación operativos, sectores política y socialmente "seguros", arrastran tendencias empresariales, persiguen el cambio social mediante un papel impulsor o catalizador, y mantienen su preferencia por el control a costa de la coordinación entre actores. Estos enfoques son lógicos dado el contexto pero no son el objetivo final ideal, sino más bien un paso hacia el fomento de la filantropía de personas con patrimonio elevado (HNWI) en el país. El presente trabajo será de interés para aquellos que tratan de relacionarse con filántropos y fundaciones hindúes, y dados los limitados eruditos existentes en la filantropía hindú, contribuye al desarrollo de teorías específicas de la India.

Keywords Organizational context - Self-determination theory $\cdot$ Motivation .

Volunteers 


\section{Introduction}

Within the last decade, many researchers have sought to understand the motivation involved for people to begin a volunteer engagement, thus concentrating on the antecedents of volunteering (cf. Wilson 2012). However, the antecedents that initially drive volunteers need to be differentiated from what makes volunteers continue their engagement in the long term (Haski-Leventhal and Bargal 2008; Millette and Gagné 2008; Pearce 1993; Penner et al. 2005). Given that volunteerism often takes place within an organizational context (Penner 2002), its characteristics might play a key role in sustained volunteer motivation. Nevertheless, the organizational context has long been neglected (Grube and Piliavin 2000; Haivas et al. 2012a; Lo Presti 2012; Wilson 2012). Grube and Piliavin (2000) therefore suggested that future volunteer research should "attempt to relate structural features of the organization to motivation of volunteers" (p. 1118). The aim of the present study is to shed light on the experience of volunteering, as Wilson (2012) described it, instead of on its antecedents, and to understand how the organizational context of non-profit organizations (NPOs) can influence the motivation and work behaviors of volunteers.

Consequently, we assume the organizational context to be crucial for successful volunteer management. However, a unique attribute of NPOs that depend on a voluntary workforce needs to be addressed: Essentially, NPO managers must assure the proper and sustained functioning of the organization, but at the same time they lack instrumental means, such as money and job security (Boezeman and Ellemers 2008; Grube and Piliavin 2000; Millette and Gagné 2008; Pearce 1993). Musick and Wilson (2008) outlined their situation as follows:

"Volunteer administrators face a dilemma: They must foster the volunteer spirit of those who have offered their services for free, but they must also control that spirit to meet organizational needs. They want to energize their volunteers but also to discipline them, and they are denied of the methods of energizing and controlling available to people who manage paid employees" (Musick and Wilson 2008, p. 429)

Thus, a challenge for NPO management is to maintain motivation without applying pressure on the volunteers. Even though volunteers join a particular organization because they want to support its objectives (Pearce 1993; Penner et al. 2005) and therefore presumably bring high motivation to help a cause, as a matter of fact, a volunteer's motivation to continue decreases once pressure to participate is perceived (Stukas et al. 1999). In particular, when it comes to fulfilling organizational duties, a voluntary workforce can create a dilemma situation, as these activities are often not directly linked to the cause or clients of the NPO and as such might be perceived as inappropriate in the eyes of a volunteer. To address this dilemma, Grube and Piliavin (2000) differentiated between two role identities that a volunteer may develop over time and that the NPO needs to nurture in order to achieve favorable volunteer outcomes: a general-role identity and a specific-role identity that is particularly linked to the organization. We adopted this line of thought and applied it to the motivational context, as we believe that the 
psychological disparity between activities that benefit the cause versus activities that benefit the NPO itself is especially relevant for volunteers. The innovative aim of the present study, therefore, is not only to understand how the organizational context influences volunteer motivation and work behavior, but also to distinguish between general volunteer motivation and organization-specific motivation.

In order to illuminate the underlying motivational process and to identify the factors that might benefit or thwart it, we applied self-determination theory (SDT; Deci and Ryan 1985, 2008). Typically, when it comes to research on volunteer motivation, the functional approach of Clary et al. (1998) is often referenced. However, this approach, which identified six psychological functions to explain why people volunteer, differs from what is intended in the present study. Our focus is rather on the quality of motivation that is experienced, not the motives (or reasons) why people volunteer. The aim of the present study therefore is to explore the extent to which volunteers experience choice and volition during their activity at the NPO. Before further introducing our present study, we briefly reprise SDT.

\section{Self-determination Theory}

SDT is a theory that aligns different qualities of (work) motivation on a continuum from controlled to self-determined motivation (Deci and Ryan 2000; Gagné and Deci 2005). Whereas controlled motivation is described as "acting with a sense of pressure, a sense of having to engage in actions", self-determined motivation is defined as "acting with a sense of volition and having the experience of choice" (Gagné and Deci 2005, p. 334). As such, the SDT continuum reflects the extent to which people have internalized external values, attitudes, or regulatory structures (Gagné and Deci 2005).

Some authors have successfully applied SDT to the volunteering field and demonstrated its unique value in research on volunteer motivation (cf. Bidee et al. 2012; Haivas et al. 2012a, b; Millette and Gagné 2008). However, Millette and Gagné (2008) recommended focusing on self-determined motivation only, as the levels of controlled motivation were reported to be quite low for volunteers and the relationships found for paid-work settings could not be replicated. Therefore, in this contribution, we did not measure controlled motivation but distinguished two foci of self-determined motivation instead.

According to Vallerand's Hierarchical Model of Intrinsic and Extrinsic Motivation of (1997), self-determined motivation can be measured at different levels of generality: the global level (i.e., general orientation), the contextual level (e.g., education, work, leisure, interpersonal relationships), and the situational level (e.g., specific tasks). Also Fernet (2011) indicated that an overall measurement of motivation ignores the different work activities involved. We adopted this line of thought and assumed that a distinction of various activities is particularly essential within the context of volunteer work. Similar to Grube and Piliavin (2000) who differentiated two role identities of volunteers (a general-role identity and an organization-specific role identity), we differentiated general and organizationspecific self-determined motivation (organization-focused SDM), which forms the core message of the present contribution. 


\section{Two Foci of Self-determined Motivation}

In this study, we assumed two processes to be highly relevant for NPO managers: (1) maintaining the high self-determined motivation of volunteers toward the cause when they meet organizational reality and (2) facilitating the internalization of organizational (thus external) values, attitudes, and regulatory structures in order to insure the functioning of the organization itself. Consequently, the NPOs need to enhance two motivational foci in volunteers: a general self-determined motivation (general SDM) and an organization-focused self-determined motivation.

\section{General Self-determined Motivation}

First, the NPO needs to preserve the high self-determined motivation of the volunteer regarding the cause and clients of the organization. People usually start volunteering because they find it interesting and because they are convinced that the activities are important and meaningful (cf. Clary et al. 1998). As there is no financial necessity for people to commence a voluntary activity, we suppose they are likely to act upon a certain sense of choice and volition. Nevertheless, the organization still needs to make sure that this generally high motivation to be active for the cause is not thwarted when the volunteer meets the organizational reality. Stukas et al. (1999) and Grube and Piliavin (2000) reported that the intent to volunteer diminishes when people feel pressured to participate. To avoid this, the NPO needs to enhance a general SDM of volunteers, which is hereafter referred to as general SDM and described as the volunteers' motivation to fulfill core volunteer activities (i.e., those activities that are closely related to the personal goals of the volunteer and directly benefit the cause and clients of the volunteer organization).

\section{Organization-Focused Self-determined Motivation}

Second, the NPO depends on the volunteers' willingness to perform activities that are in line with their personal mission, as well as those activities that primarily benefit the organization itself. For example, these activities include complying with organizational rules and regulations, consciously acting in administrative tasks, showing loyalty toward the organization or making suggestions that improve the organization. Although volunteers are representatives of the organization-just as paid workers - they do not feel as affiliated as paid workers do (Haski-Leventhal and Bargal 2008, p. 71). Consequently, the internalization of organizational values and acceptance of its mission and regulatory structures is particularly essential for NPOs due to the lack of instrumental means to motivate or sanction the workforce (Grube and Piliavin 2000; Pearce 1993). Successful internalization should lead to the development of an organization-focused self-determined motivation, which we hereafter refer to as organization-focused SDM and describe as the volunteers' motivation for activities that are primarily beneficial to the organization itself (i.e., those activities that are further away from the volunteers personal goals and initial expectations). 


\section{The Present Study}

In short, the present study aimed to shed light on the influence of the organizational context on volunteer motivation and work behaviors. We hypothesized that the challenge of NPO managers to insure a proper and sustained functioning of the organization is to nurture two foci of motivation. These two foci-the motivation to work for the cause and clients (general SDM) and the motivation to work for the organization itself (organization-focused SDM) — are predicted by diverse organizational antecedents and, moreover, separately account for positive work outcomes. In the following, the specific hypotheses are presented.

\section{Organizational Context}

In this study, the organizational context is reflected from three different perspectives: the characteristics of the volunteer tasks (motivational potential of the tasks), the social context in which the activity is performed (autonomy supportive leadership), and the perception of the organizational mission (value congruence).

\section{Motivational Potential of the Tasks}

With regard to the volunteer tasks, the motivational potential is introduced as an antecedent of motivation. According to the job characteristics model (JCM; Hackman and Oldham 1976), five particular characteristics influence motivation (cf. Morgeson and Humphrey 2006):

- Autonomy reflects the extent to which a job allows freedom, independence, and discretion to schedule work, make decisions, and choose the methods used to perform tasks.

- Task identity reflects the degree to which a job involves a whole piece of work, the results of which can be easily identified.

- Task variety refers to the degree to which a job requires employees to perform a wide range of tasks on the job.

- Task significance reflects the degree to which a job influences the lives or work of others.

- Feedback from the job reflects the degree to which the job provides direct and clear information about the effectiveness of task performance.

These five characteristics can be calculated into an overall motivational potential score (MPS). Jobs with a high MPS are known to have a positive relation with various outcomes, such as motivation and performance (Gagné and Deci 2005; Hackman and Oldham 1976). From SDT literature it is known that the MPS also predicts the quality of motivation, depending on its autonomy supportiveness (Gagné and Deci 2005). Even though the motivational potential of tasks is highly relevant for contemporary workplaces (Parker and Ohly 2008), task characteristics have long been neglected in the volunteer context. Millette and Gagné (2008) were the first to show that the motivational potential of the tasks is indeed positively 
correlated with self-determined motivation, satisfaction, and performance of volunteers. In order to replicate this finding, our first hypothesis is as follows:

H1a A high motivational potential of the tasks has a positive effect on selfdetermined motivation of volunteers.

In particular, we expect volunteers to see the cause and clients as their core activities rather than activities insuring the functioning of the organization. We assume the motivational potential of their tasks to be subjectively stronger related to core activities and thus to primarily affect general SDM. Accordingly, the existence of, for example, a certain amount of autonomy in decision-making, perceived significance for other people, and variation in tasks should mainly enhance the volunteers' experience of joy and identification with core volunteer activities, and to a lesser extent lead to internalization of external values, that is organization-focused SDM:

H1b The motivational potential of the tasks particularly affects general SDM more than organization-focused SDM of the volunteers.

\section{Autonomy Supportive Leadership}

In addition to task characteristics, the social context is known to predict the quality of motivation (Gagné and Deci 2005). SDT states that one of these social context factors is the autonomy support of the work-group supervisor (Baard et al. 2004). Autonomy support means, for example, that the supervisor shows interest in the employee's perspective, encourages them to ask questions and communicates trust in their skills. In fact, the positive impact of autonomy supportive leadership on employee outcomes, such as self-motivation, satisfaction, and performance, has been researched extensively (Baard et al. 2004; Gagné and Deci 2005). Based on the paid-work findings of Baard et al. (2004) and in line with Haivas et al. (2012a) who transferred it to the volunteer setting, our second hypothesis is as follows:

H2a Autonomy supportive leadership positively effects the self-determined motivation of volunteers.

Moreover, a supervisor that supports the autonomy of the volunteers in their core activities for the cause and clients should benefit their general SDM in a similar way to the impact of a high motivational potential of the tasks. However, a supervisor also clearly represents the organization and may give a rationale to fulfill those activities that primarily benefit the organization itself, which means that an autonomy supportive supervisor also enhances the internalization of external values and thus promotes the organization-focused SDM of volunteers. Therefore, it is hypothesized that there will be similar effects on both motivational foci:

H2b An autonomy supportive supervisor similarly influences general SDM and organization-focused SDM of volunteers. 


\section{Value Congruence}

With regard to the perspective of the organizational mission, value congruence is introduced as an antecedent of motivation. Wright and Pandey (2008) stated that employees show more work motivation, satisfaction, and performance once they perceive value congruence, that is "the extent to which the employee perceives that his or her values are congruent with those of the [...] organization he or she works for" (p. 502). Greguras and Diefendorff (2009) showed that this aspect of personorganization fit was strongly related to satisfaction of the basic need for autonomy, which in turn is linked to self-determined motivation (Van den Broeck et al. 2010). Moreover, the possibility to express personal values is one of the most important motives to start volunteering (cf. Clary et al. 1998). Therefore, it is hypothesized that value congruence is particularly crucial for volunteer motivation.

H3a Value congruence between volunteer and organization benefits the selfdetermined motivation of volunteers.

According to Grube and Piliavin (2000) congruence between the volunteers' values and those of the organization should foster the development of an organization-specific role identity. They found that the appropriate use of funds was indeed positively related to organization-specific role identity. In the present study, this finding was expanded to a broader measurement of value congruence than the appropriate use of funds. Value congruence should facilitate the internalization of external values and regulatory structures and thus result in selfdetermined motivation, which should, in particular, increase the motivation of the volunteers for activities that benefit the organization itself-their organizationfocused SDM:

H3b Value congruence particularly influences organization-focused SDM more than general SDM of volunteers.

\section{Outcomes}

Self-determined motivation is known to be a reliable predictor of work outcomes, such as job satisfaction, commitment, organizational trust, psychological wellbeing, or citizenship behavior (Gagné and Deci 2005). In the present study, work engagement (Schaufeli and Bakker 2004) and organizational citizenship behavior (OCB; Organ 1988) were measured as outcome variables with a different emphasis: Compatible to the two motivational foci, work engagement describes a more general persistent affective-cognitive state, whereas OCB reflects concrete organizational work behaviors.

\section{Work Engagement}

Work engagement is defined as a positive, fulfilling, work-related state of mind that is characterized by vigor, dedication, and absorption (Schaufeli et al. 2002). Work engagement, which is often considered as an antipode of burnout (Schaufeli et al. 
2006), has been found to be positively related to job resources, such as social support from supervisors or the motivational potential of tasks (cf. Bakker and Demerouti 2008). Vecina et al. (2012) evaluated the usability of work engagement within the volunteering context and argued that work engagement is "of great practical interest for the management of non-profit organizations" (p. 143). In turn, Van Beek et al. (2012) showed that high levels of work engagement were associated with high levels of intrinsic motivation for the paid-work context. For the volunteer context, Haivas et al. (2012b) reported that work engagement-measured by an adapted volunteers' engagement scale proposed by Gagné (2003)—was positively correlated with self-determined motivation. Building on these findings, we specified that especially general SDM, which reflects the joy at and identification with core volunteer activities, should lead to the experience of more work engagement.

H4a Self-determined motivation positively influences the work engagement of volunteers.

H4b In particular, general SDM has a stronger influence on the work engagement of volunteers than organization-focused SDM.

\section{Organizational Citizenship Behavior}

The second outcome in the present study is OCB (Organ 1988). Penner et al. (2005) understood OCB as a voluntary behavior and as such, as one kind of volunteering. We understand OCB to be voluntary behavior within an organizational context, which, might, as such, occur both in profit and nonprofit organizations. This is in line with both Musick and Wilson (2008) who argued that citizenship is not conceptually identical with volunteering, and Millette and Gagné (2008), who measured OCB as one indicator of volunteer performance. Surprisingly, Millette and Gagné (2008) did not find any evidence that self-determined motivation was correlated to OCB. We assume that they did not find any effects due to their general focus of motivation (here called general SDM). As OCB is defined as a set of "individual behavior, that [...] in the aggregate promotes the efficient and effective functioning of the organization" (Organ 1988, p. 4), we assume that organizationfocused SDM would be more strongly correlated to OCB. Furthermore, because we were interested in behaviors that benefit the organization (and not volunteer colleagues), we focused on the OCB-O dimension, which has previously been labeled as generalized organizational compliance (Podsakoff et al. 2000; Williams and Anderson 1991).

H5a Self-determined motivation positively influences the OCB of volunteers.

H5b Specifically, organization-focused SDM has a stronger influence on the OCB of volunteers than general SDM.

The complete hypothesized research model is illustrated in Fig. 1. Please note that previous studies showed significant correlations between organizational antecedents and outcomes (e.g., Baard et al. 2004; Millette and Gagné 2008; Wright and Pandey 2008). However, as the focus of the present study was on 


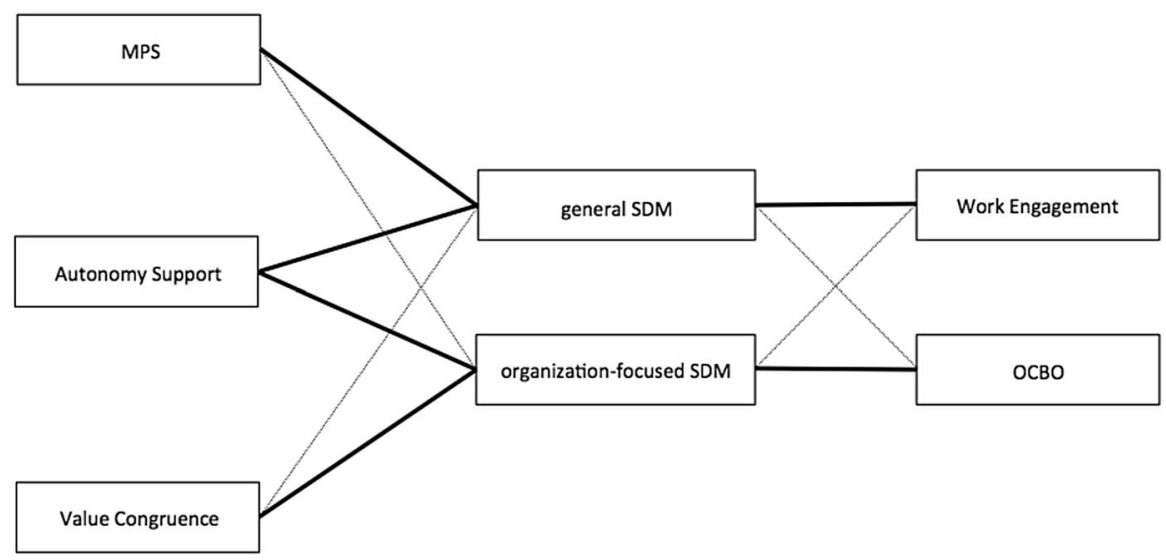

Fig. 1 Hypothesized research model (M1). MPS Motivational potential of the tasks. The thickness of the lines reflects the postulated strength of the relationships between antecedents, outcomes, and the two foci of motivation. Note that direct effects are not displayed due to legibility reasons

differential effects of self-determined motivation, we decided not to mark any direct paths in Fig. 1 for legibility reasons.

\section{Method}

Procedure

In order to test the deduced hypotheses, we surveyed volunteers from four major social-care organizations in Switzerland: the Red Cross, Caritas, and two local NPOs providing services for elderly people and telephone counseling, respectively. After semi-structured interviews and review processes with the coordinators of the participating organizations, we conducted a pre-test with a random sample of 83 volunteers. Thereupon, the coordinators of the organizations sent the surveys to a total of 5,515 volunteers. A broad variety of volunteer activities and causes ranging from a visiting service for elder and isolated people, a driving service for disabled people, an SOS-helpline for people in need, a social support service for patients referred by general practitioners, a refugee aid service, an integration project for migrant children, to a career entry support services for juveniles and more was represented. In order to insure that the questioned volunteers possessed some substantial knowledge about their organizations and showed certain continuity in engagement (i.e., no event or short-time volunteering), only those volunteers were addressed that volunteered minimum $3 \mathrm{~h}$ per week. Surveys could be completed either online or in paper-pencil form. The sequence of the questions was harmonized between both survey forms. All surveys were returned to the investigators directly, whereas the paper forms included a self-addressed postagepaid envelope. 


\section{Participants}

Our results are based on the data of 2,222 volunteers, which corresponds to a response rate of $40 \%$. The mean age of the sample was 63.68 years $(S D=11.56)$, and $61.3 \%$ of the sample was female. Participants worked on average $3.75 \mathrm{~h}$ per week for the organization $(S D=3.25)$, on average for 6.35 years $(S D=6.34)$ in their current organization and, more generally, for 12.41 years $(S D=12.47)$ as a volunteer. Overall, these demographics are in line with nationwide findings about Swiss volunteers (cf. Stadelmann-Steffen et al. 2010).

\section{Measures}

All scales were adapted to the volunteering context: "Job" was replaced with "volunteer activity" and "manager" was replaced with "responsible coordinator". Reliabilities of the scales are reported in Table 1.

\section{Motivational Potential of the Tasks}

Morgeson and Humphrey (2006) introduced the Work Design Questionnaire (WDQ) as an extension of the JDS (Hackman and Oldham 1975). We used the German version of the WDQ by Stegmann et al. (2010) and focused on the five task characteristics: (1) decision-making autonomy (3 items; sample item "The job allows me to make a lot of decisions on my own"); (2) task identity (4 items; sample item "The job allows me to complete work I start"); (3) task variety (4 items; sample item "The job involves doing a number of different things"); (4) feedback from job (3 items; sample item "The job itself provides me with information about

Table 1 Means, standard deviations, internal consistencies (Cronbach's Alpha), and intercorrelations among variables

\begin{tabular}{llllllllll}
\hline Variable & $M$ & $S D$ & 1 & 2 & 3 & 4 & 5 & 6 & 7 \\
\hline $\begin{array}{l}\text { 1. Motivational potential of the tasks } \\
\text { (WDQ) }\end{array}$ & 43.50 & 25.29 & $\mathrm{a}$ & & & & & \\
2. Autonomy supportive leadership & 4.04 & 0.77 & .35 & $(.89)$ & & & & & \\
$\quad$ (WCQ) & & & & & & & & & \\
3. Value congruence & 3.64 & 0.78 & .26 & .29 & $(.75)$ & & & \\
4. General SDM & 4.30 & 0.57 & .42 & .33 & .29 & $(.85)$ & & \\
5. Organization-focused SDM & 3.67 & 0.81 & .27 & .30 & .46 & .28 & $(.81)$ & \\
6. Work engagement & 4.95 & 1.13 & .36 & .27 & .29 & .58 & .28 & $(.93)$ \\
7. OCBO & 2.93 & 0.78 & .30 & .20 & .51 & .26 & .54 & .29 & $(.85)$ \\
\hline
\end{tabular}

$N=2,222 ;$ all intercorrelations $p<.001$

$W D Q$ Work Design Questionnaire (Stegmann et al. 2010), WCQ Work Climate Questionnaire (Baard et al. 2004), general SDM general self-determined motivation, organization-focused SDM organizationfocused self-determined motivation, $O C B O$ organizational citizenship behavior directed to the organization (Lee and Allen 2002)

a Alphas of the tasks characteristics range from .78 to .84 
my performance"); (5) task significance (4 items; sample item "The results of my work are likely to significantly affect the lives of other people"). For time reasons, we focused on decision-making autonomy only, as Stegmann et al. (2010) reported the best methodological characteristics and correlations with outcomes for this autonomy subscale (compared to work scheduling and work methods autonomy). All questions were rated on a 5-point scale ranging from 1 (not agree) to 5 (I agree) and calculated into an overall MPS (Hackman and Oldham 1975).

\section{Autonomy Supportive Leadership}

Baard et al. (2004) introduced the Work Climate Questionnaire (WCQ) to measure the perceived autonomy support of supervisors. We used the short version, which contains six items. A sample item reads "My manager provides me with choices and options about my work". The response scale ranged from 1 (not agree) to 5 (I agree).

\section{Value Congruence}

Perceived value congruence between organization and volunteer was measured with the 4-item scale created by Wright and Pandey (2008) which was rated on a 5-point scale ranging from 1 (not agree) to 5 (I agree). A sample item reads "I find that my values and the organization's values are very similar."

\section{Self-determined Motivation (General and Organization-Focused SDM)}

We measured general SDM using an adapted version of the Multidimensional Work Motivation Scale (MWMS; Gagné et al. 2014). The scale consists of 8 items that are equally divided into two subscales: intrinsic motivation and identified regulation. Participants were asked: "Why do you put effort in your volunteer activity?" Sample items read "Because I enjoy my volunteer activity very much" (intrinsic) or "Because what I do in my volunteer activity has a lot of personal meaning to me" (identified). Items were rated on a 5-point scale ranging from 1 (not agree) to 5 (I agree).

To address organization-focused SDM, we created a separate scale, based on the MWMS (Gagné et al. 2014) that consisted of two intrinsic and four identified regulation items. Instead of posing an abstract question "Why do you put effort for your organization?" (analogous to general SDM), we provided for two more concrete introductory questions, which read "Why do you speak positively about the organization?" and "Why do you come forward with ideas that benefit the organization?". The idea of these introductions was to give participants an example for possible contents of organization-focused SDM. The items, however, were fully in line with SDT conceptualization of intrinsic motivation and identified regulation. Sample items read "Because I enjoy speaking about the organization" (intrinsic), or "Because helping on the organization is of personal significance to me" (identified). Answer format was a 5-point scale ranging from 1 (not agree) to 5 (I agree). All SDT items are listed in Appendix. 


\section{Work Engagement}

Work engagement was measured with the short 9-item version of the Utrecht Work Engagement Scale (UWES; Schaufeli and Bakker 2003). Sample items read: "At my volunteer activity, I feel strong and vigorous" (vigor), "I am proud of my volunteer activity"(dedication) and "I am immersed in my volunteer activity" (absorption). Items were rated on a 7-point scale ranging from 1 (never) to 7 (always).

\section{Organizational Citizenship Behavior (OCB)}

Based on Williams and Anderson (1991), Lee and Allen (2002) developed an 8-item OCBO scale for those behaviors that are particularly directed to the organization, which was rated on a 5-point scale ranging from 1 (never) to 5 (always). A sample items reads "How often do you take action to protect the organization from potential problems?"

\section{Analytical Strategy}

In order to demonstrate discriminant validity of general and organization-focused SDM, we calculated an exploratory factor analysis (EFA) with a fixed number of two factors. Then, we analyzed the correlation patterns and calculated a path model as implemented by AMOS 19.0 to test our research model as illustrated in Fig. 1. To further endorse the postulated significant differences between the path coefficients (H1b-H5b), we tested an additional nested model for each hypothesis, in which the respective paths on general and organization-focused SDM were held equal. If the additional nested model showed a significant decline in fit indices, we concluded that the paths were not equal, thus that they had differential effects. Participants with missing data in the requested variables were deleted listwise, reducing the $N$ for the test of $\mathrm{H} 1 \mathrm{~b}, \mathrm{H} 2 \mathrm{~b}, \mathrm{H} 3 \mathrm{~b}, \mathrm{H} 4 \mathrm{~b}$, and $\mathrm{H} 5 \mathrm{~b}$ to a total of 1,800 participants.

\section{Results}

The means, standard deviations, intercorrelations, and reliabilities of the scales are shown in Table 1. The EFA clearly separated between general and organizationfocused SDM and is illustrated in Table 2.

The correlations between the antecedents, the outcomes, and self-determined motivation were all positive and in line with the postulated hypotheses H1a, H2a, $\mathrm{H} 3 \mathrm{a}, \mathrm{H} 4 \mathrm{a}$, and H5a. A comparison of the bivariate correlations for significant differences using $t$ tests gave us a first indication whether our H1b, H2b, H3b, H4b, and $\mathrm{H} 5 \mathrm{~b}$ were accurate. Indeed, the motivational potential of the tasks was significantly stronger correlated to general than to organization-focused SDM, $t(2221)=-6.59, p<.001$, value congruence was significantly stronger correlated to organization-focused than to general SDM, $t(2221)=-7.65, p<.001$, whereas autonomy supportive leadership showed no significant difference, $t(2221)=-1$. 
Table 2 Factor loadings from principal components analysis with varimax rotation

\begin{tabular}{lll}
\hline Scale and items & F1 & F2 \\
\hline General SDM & .781 \\
Because I enjoy my volunteer activity very much & .798 \\
Because what I do in my volunteer activity is exciting & .769 \\
Because my volunteer activity is interesting & .777 \\
Because my volunteer activity is a lot of fun & .602 \\
Because I personally consider it important to put efforts in my volunteer activity & .473 \\
Because it aligns with my values to put efforts in my volunteer activity & .614 \\
Because putting efforts in my volunteer activity is of personal significance to me & .682 \\
Because what I do in my volunteer activity has a lot of personal meaning to me. & \\
Organization-focused SDM & .558 \\
Because I enjoy speaking about the organization & .775 \\
Because I enjoy thinking ahead for the organization & .660 \\
Because I personally consider it important to properly represent the organization & .640 \\
Because I align myself with the organization & .794 \\
Because helping on the organization is of personal significance to me & .762 \\
Because I find it important that issues for (organizational) improvement are raised & \\
\hline
\end{tabular}

This solution accounted for $51 \%$ of the total variance. Loading $<.30$ not shown

$28, p=.100$. Also, general SDM was significantly stronger correlated to work engagement than to OCB-O, $t(2221)=-14.62, p<.001$, whereas organizationfocused SDM was significantly stronger correlated with OCB-O than with work engagement, $t(2221)=-13.18, p<.001$. These correlation patterns fully supported all our hypotheses.

Our initially hypothesized research model (M1; Fig. 1) did not fit the data $\chi^{2}$ $(N=1,800, d f=6)=41.94, p<.001$, as indicated by the goodness-of-fit statistics displayed in Table 3. Based on theoretical considerations and modification indices, we additionally allowed for the direct effects from the motivational potential of the tasks on work engagement and from value congruence on OCBO. Moreover, we removed the insignificant path from general SDM to OCBO. The adjusted model (M2) showed a better fit to the data, but was still unsatisfying $\chi^{2}$ $(N=1,800, d f=5)=9.57 ; p<.001$. We allowed for another two direct effects from the motivational potential of the tasks on OCBO and from value congruence on work engagement, resulting in our final research model (M3), which fit the data best: $\chi^{2}(N=1,800, d f=3)=2.10 ; p=.097$. The resulting model is displayed in Fig. 2.

Along the lines of the correlation patterns (Table 1) and the $t$ tests, the comparison of the standardized path coefficients fully support our $\mathrm{H} 1 \mathrm{~b}, \mathrm{H} 2 \mathrm{~b}$, and $\mathrm{H} 3 \mathrm{~b}$ : The effect of the motivational potential of the tasks on general SDM $(\beta=.32$, $p<.001)$ was stronger than on organization-focused $\operatorname{SDM}(\beta=.12, p<.001)$, supporting H1b. Autonomy supportive leadership showed slightly but not significantly stronger effects on general than on organization-focused SDM $(\beta=.18$, $p<.001$ and $\beta=.14, p<.001$ ), which supports H2b. H3b was also accepted, since 
Table 3 Summary of fit statistics

\begin{tabular}{lrlrlrrr}
\hline Model & $\chi^{2}$ & $d f$ & $\chi^{2} / d f$ & RMSEA & CFI & NFI & TLI \\
\hline 1. Hypothesized model (M1) & 251.67 & 6 & 41.94 & .151 & .924 & .923 & .734 \\
2. Adjusted model (M2) & 47.84 & 5 & 9.57 & .069 & .987 & .985 & .944 \\
3. Resulting model (M3) & 6.31 & 3 & 2.10 & .025 & .999 & .998 & .993 \\
\hline
\end{tabular}

$N=1800$

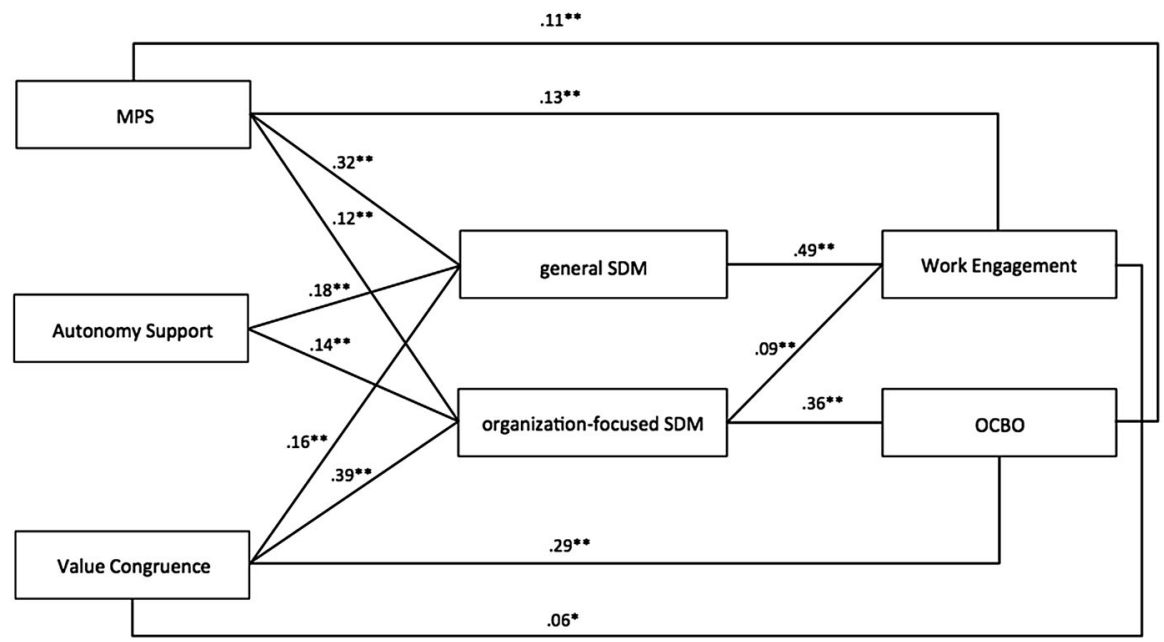

Fig. 2 Resulting research model (M3). MPS Motivational potential of the tasks

value congruence showed a stronger effect on the organization-focused SDM $(\beta=.39, p<.001)$ than on general $\operatorname{SDM}(\beta=.16, p<.001)$. Moreover, we see that work engagement was mainly explained by general $\operatorname{SDM}(\beta=.47, p<.001)$, but also organization-focused SDM could explain some additional variance even though to a much smaller extent $(\beta=.09, p<.001)$. Remarkably, OBCO was only explained by organization-focused $\operatorname{SDM}(\beta=.37, p<.001)$ as we had to remove the path from general SDM on OCBO. These findings support H4b and H5b. To further test the significance of the postulated differences between the path coefficients (H1b-H5b), we calculated five additional nested path models for each hypothesis, in which we set two paths equal at a time and checked for significant declines in the fit indices. The additional nested models caused significant declines in fit indices: regarding the motivational potential of the tasks (H1b), $\mathrm{CMIN}=16.874, p<.000, \mathrm{NFI}=.01, \mathrm{TLI}=.02$; regarding value congruence, $\mathrm{CMIN}=115.943, p<.000, \mathrm{NFI}=.04, \mathrm{TLI}=.19$; regarding work engagement, $\mathrm{CMIN}=224.953, \quad p<.000, \quad \mathrm{NFI}=.07, \quad \mathrm{TLI}=.48 ;$ and regarding OCB-O, $\mathrm{CMIN}=71.852, p<.000, \mathrm{NFI}=.02, \mathrm{TLI}=.15$. The fit indices regarding autonomy supportive leadership $(\mathrm{H} 2 \mathrm{~b})$ did not significantly decline: $\mathrm{CMIN}=0.157, p=.692$, NFI $=.00$, TLI $=-.00$. This is perfectly in line with 
our assumptions, as we postulated the effect of autonomy supportive leadership to be equal for both foci of SDM (H2b). For all other hypotheses, the model fit was better when the paths are allowed to differ. We conclude that all our hypotheses H1b-H5b were supported.

\section{Discussion}

The aim of the present study was to understand how the organizational contextoperationalized by the motivational potential of the tasks (volunteer tasks), autonomy supportive leadership (social context), and perceived value congruence (organizational mission) - affects volunteer motivation and work behaviors. Hence, the present study shed light on the experience of volunteering and, as such, addressed an important research question (cf. Grube and Piliavin 2000; Haivas et al. 2012a; Haski-Leventhal and Bargal 2008; Pearce 1993; Penner et al. 2005; Wilson 2012). Bearing in mind the challenge for NPOs to manage a volunteer workforce without applying pressure, we used self-determination theory (Deci and Ryan 1985, 2008; Millette and Gagné 2008) to illustrate underlying motivational processes. In particular, we differentiated between two foci of volunteer motivation: a general SDM and an organization-focused SDM.

As hypothesized, all aspects of the organizational context had a positive impact on self-determined motivation of volunteers and predicted the two motivational foci differentially: Whereas general SDM was mainly explained by the motivational potential of the volunteer tasks, the perceived value congruence with the organization accounted for the motivation to work for the organization itself (organization-focused SDM). Autonomy supportiveness of the supervisor similarly influenced both foci of motivation. Furthermore, the two motivational foci differentially affected volunteer outcomes: The experience of general SDM enhanced the work engagement of volunteers, whereas the experience of organization-focused SDM mainly explained the frequency of OCBs of volunteers. Especially in the case of the practically relevant OCBO, the inclusion of organization-focused SDM as a separate focus proves to be worthwhile given that in the study by Millette and Gagné (2008) self-determined motivation could not predict this important outcome. Without the consideration of organization-focused SDM, the full impact of the antecedents on OCBO could not have been explained. Moreover, the experience of organization-focused SDM not only enhances the OCBO of the volunteers, but also their work engagement although to a smaller extent. Consequently, we conclude that both foci of self-determined motivation are important for favorable volunteer behaviors.

In line with Musick and Wilson (2008), we agree that it is challenging for NPOs to meet both requirements, that is, to energize but also discipline volunteers. However, our study shows different ways in which NPO managers can maintain and enhance volunteer motivation:

- First, self-determined motivation of volunteers, particularly toward core activities involving the cause and clients of the NPO can be retained when the volunteer tasks are designed to enhance the motivational potential. This 
means that volunteers should experience independence in decision-making (autonomy), have diversified tasks (variety), feel involved in the activity from the beginning until the end (identity), feel that their work is important for others (significance), and get some direct information about their performance (feedback). The allocation of well-designed tasks that stimulate the joy and identification of volunteers with their core activities in turn benefits their vitality, absorption, and dedication. But not only does this joy and identification with core activities enhance work engagement; it also increases the volunteers' intent to remain (cf. van Schie et al. 2013; Haivas et al. 2013).

- Second, autonomy supportive behaviors of supervisors are directly linked to both foci of motivation and, as such, may mitigate the dilemma NPOs are confronted with: Supervisors have the opportunity to give a rationale for organizational needs and, thus, play a key role in transforming the experience of potentially pressuring organizational requirements into self-determined motivation maintaining the proper and sustained functioning of the NPO. Moreover, NPO supervisors should, whenever possible, support choice and volition of volunteers in carrying out their core activities.

- Third, if volunteers are needed for activities that mainly benefit proper and sustained functioning of the organization, NPOs should be aware of how important value congruence is. This implies that organizational values should be communicated clearly and be visible in both strategy and daily business. In general, the internalization of the NPOs' values, attitudes, and regulatory structures is essential with respect to volunteer behaviors that promote an efficient and effective functioning of the NPO. Simple joy of being a volunteer and identification with the cause and clients are not sufficient.

- Fourth, organization-focused SDM may not only foster OCBs, but also other relevant outcomes, such as the development of an organization-specific role identity, or organizational commitment. For NPOs that struggle with high volatility of their workforce, organization-specific role identity or commitment is crucial. For example, Grube and Piliavin (2000) showed that a strong organization-specific role identity enhanced the number of hours exclusively volunteered for the particular NPO. High volunteer motivation for activities related to the NPO may support organizational commitment to the NPO accordingly.

All in all, the present paper indicates how to get a better hold of a relatively volatile workforce through actively supporting specific foci of volunteer motivation and without exerting inadequate pressure on volunteers. As such, our paper illustrates how sustained collective action can be achieved by fostering the individual experiences of self-determination.

\section{Limitations and Future Studies}

There are several limitations of the present study, which need to be addressed. First, the study was based on a cross-sectional design, which limits the causal interpretation of the findings. Future longitudinal studies may further clarify the development of the motivational foci over time. Second, the fact that all data were 
gathered with the same survey brings up the topic of common method variance (CMV). CMV is believed to inflate relationships due to measuring with the same method (Podsafkoff et al. 2003). However, Siemens et al. (2010) concluded that CMV is less problematic in more complex estimations (i.e., multivariate linear relationships), simply because more independent variables are included in the estimation. Also Spector (2006) expressed doubts that the method itself inflates correlations to any significant degree and suggested to instead carefully analyze the "purpose and the nature of our desired inferences" (p. 228). Accordingly, as this study's focus was on the differential associations and not so much on their absolute strength, we do not expect CMV to change the reported patterns. Third, the mean age of 63 years of the participants was quite high. However, this corresponds to the demographics of the volunteer population, as volunteer rates remain high until the age of 80. Moreover, the sample size of the present study was extensive, contained diverse volunteer activities, and as such, provides ecological validity. Nevertheless, future studies may take into consideration other volunteer contexts than the social sector. Fourth, our two foci of self-determined motivation remain accentuations. As Fernet (2011) indicated, even within one-and-the-same work domain, the motivational quality of specific tasks or roles can differ significantly. Therefore, certain aspects or activities might be perceived as controlling, even though the job as a whole is described as self-determined. In order to achieve more selective foci, future volunteer research could further specify different activities. Nevertheless, scales with higher discriminatory power should not diminish the reported results but, on the contrary, only lead to clearer and even enforced results. Finally, future studies could address additional aspects of the organizational context which influence the quality of motivation, such as organizational justice, team cohesion, the hierarchical structure of the organization, or internal information flow.

\section{Conclusion}

This study replicates and extends earlier research by Millette and Gagné (2008) and sheds additional light on the influence of the organizational context on the individual motivation, as well as work behaviors. The innovative contribution of this study is that it differentiates between two motivational foci of volunteers: a general SDM and an organization-focused self-determined motivation. General and organization-focused self-determined motivation showed impressive differential associations with both antecedents and outcomes.

Acknowledgments This research was financially supported by the Swiss National Science Foundation (Grant No. 1000014_124444).

\section{Appendix}

General SDM (According to MWMS as of Gagné et al. (2014)

I put effort in my volunteer activity, ... 


\section{Intrinsic Motivation}

1. Because I enjoy my volunteer activity very much.

2. Because what I do in my volunteer activity is exciting.

3. Because my volunteer activity is interesting.

4. Because my volunteer activity is a lot of fun.

\section{Identified Regulation}

5. Because I personally consider it important to put efforts in my volunteer activity.

6. Because it aligns with my values to put efforts in my volunteer activity.

7. Because putting efforts in my volunteer activity is of personal significance to me.

8. Because what I do in my volunteer activity has a lot of personal meaning to me.

Organization-Focused SDM (Based on MWMS as of Gagné et al. 2014)

I put effort in my volunteer organization (e.g., speaking positively about the organization or come forward with ideas that benefit the organization)

Intrinsic Motivation

1. Because I enjoy speaking about the organization.

2. Because I enjoy thinking ahead for the organization.

\section{Identified Regulation}

3. Because I personally consider it important to properly represent the organization.

4. Because I align myself with the organization.

5. Because helping on the organization is of personal significance to me.

6. Because I find it important that issues for (organizational) improvement are raised.

\section{References}

Baard, P. P., Deci, E. L., \& Ryan, R. M. (2004). Intrinsic need satisfaction: A motivational basis of performance and well-being in two work settings. Journal of Applied Social Psychology, 34, 2045-2068.

Bakker, A. B., \& Demerouti, E. (2008). Towards a model of work engagement. Career Development International, 13, 209-223.

Bidee, J., Vantilborgh, T., Pepermans, R., Huybrechts, G., Willems, J., Jegers, M., et al. (2012). Autonomous motivation stimulates volunteers' work effort: A self-determination theory approach to volunteerism. Voluntas. doi:10.1007/s11266-012-9269-x.

Boezeman, E. J., \& Ellemers, N. (2008). Pride and respect in volunteers' organizational commitment. European Journal of Social Psychology, 38, 159-172. 
Clary, E. G., Snyder, M., Ridge, R., Copeland, J., Stukas, A. A., Haugen, J., et al. (1998). Understanding and assessing the motivations of volunteers: A functional approach. Journal of Personality and Social Psychology, 74, 1516-1530.

Deci, E. L., \& Ryan, R. M. (1985). Intrinsic motivation and self-determination in human behavior. New York: Plenum.

Deci, E. L., \& Ryan, R. M. (2000). The "what" and "why" of goal pursuits: Human needs and the selfdetermination of behavior. Psychological Inquiry, 11(4), 227-268.

Deci, E. L., \& Ryan, R. M. (2008). Facilitating optimal motivation and psychological well-being across life's domains. Canadian Psychology, 49(1), 14-23.

Fernet, C. (2011). Development and validation of the Work Role Motivation Scale for school principles (WRMS-SP). Educational Administration Quarterly, 47(2), 307-331.

Gagné, M. (2003). The role of autonomy support and autonomy orientation in prosocial behavior engagement. Motivation and Emotion, 27, 199-223.

Gagné, M., \& Deci, E. L. (2005). Self-determination theory and work motivation. Journal of Organizational Behavior, 26, 331-362.

Gagné, M., Forest, J., Vansteenkiste, M., Crevier-Braud, L., Van den Broeck, A., Aspeli, A. K., et al. (2014). The multidimensional Work Motivation Scale: Validation evidence in seven languages and nine countries. European Journal of Work and Organizational Psychology. doi:10.1080/1359432X. 2013.877892 .

Greguras, G. J., \& Diefendorff, J. M. (2009). Different fits satisfy different needs: Linking personenvironment fit to employee commitment and performance using self-determination theory. Journal of Applied Psychology, 94(2), 465-477.

Grube, J. A., \& Piliavin, J. A. (2000). Role identity, organizational experiences, and volunteer performance. Personality and Social Psychology Bulletin, 26, 1108-1119.

Hackman, J. R., \& Oldham, G. R. (1975). Development of the Job Diagnostic Survey. Journal of Applied Psychology, 60(2), 159-170.

Hackman, J. R., \& Oldham, G. R. (1976). Motivation through the design of work: Test of a theory. Organizational Behavior and Human Performance, 16, 250-279.

Haivas, S., Hofmans, J., \& Pepermans, R. (2012a). Self-determination theory as a framework for exploring the impact of the organizational context on volunteer motivation: A study of Romanian volunteers. Nonprofit and Voluntary Sector Quarterly. doi:10.1177/0899764011433041.

Haivas, S., Hofmans, J., \& Pepermans, R. (2012b). "What motivates you doesn't motivate me": Individual differences in the needs satisfaction-motivation relationship of Romanian volunteers. Applied Psychology: An International Review. doi:10.1111/j.1464-0597.2012.00525.x.

Haivas, S., Hofmans, J., \& Pepermans, R. (2013). Volunteer engagement and intention to quit from a selfdetermination theory perspective. Journal of Applied Social Psychology, 43, 1869-1880.

Haski-Leventhal, D., \& Bargal, D. (2008). The volunteer stages and transitions model: Organizational socialization of volunteers. Human Relations, 61(1), 67-102.

Lee, K., \& Allen, N. J. (2002). Organizational citizenship behavior and workplace deviance: The role of affect and cognitions. Journal of Applied Psychology, 87(1), 131-142.

Lo Presti, A. (2012). The interactive effects of job resources and motivations to volunteer among a sample of Italian volunteers. Voluntas. doi:10.1007/s11266-012-9288-7.

Millette, V., \& Gagné, M. (2008). Designing volunteers' tasks to maximize motivation, satisfaction and performance: The impact of job characteristics on volunteer engagement. Motivation and Emotion, $32,11-22$.

Morgeson, F. P., \& Humphrey, S. E. (2006). The Work Design Questionnaire (WDQ): Developing and validating a comprehensive measure for assessing job design and the nature of work. Journal of Applied Psychology, 91, 1321-1339.

Musick, M. A., \& Wilson, J. (2008). Volunteers: A social profile (philanthropic and nonprofit studies). Bloomington, IN: Indiana University Press.

Organ, D. W. (1988). Organizational citizenship behavior: The good soldier syndrome. Lexington, MA: Lexington.

Parker, S. K., \& Ohly, S. (2008). Designing motivating jobs: An expanded framework for linking work characteristics and motivation. In R. Kanfer, G. Chen, \& R. Prichard (Eds.), Work motivation: Past, present and future (pp. 233-284). New York: Routledge Academic.

Pearce, J. L. (1993). Volunteers: The organizational behavior of unpaid workers. London: Routledge.

Penner, L. A. (2002). Dispositional and organizational influences on sustained volunteerism: A interactionist perspective. Journal of Social Issues, 58(3), 447-467. 
Penner, L. A., Dovidio, J. F., Piliavin, J. A., \& Schroeder, D. A. (2005). Prosocial behavior: Multilevel perspectives. Annual Review of Psychology, 56, 365-392.

Podsafkoff, P. M., MacKenzie, S. B., Lee, J. Y., \& Podsakoff, N. P. (2003). Common method biases in behavioral research: A critical review of the literature and recommended remedies. Journal of Applied Psychology, 88, 879-903.

Podsakoff, P. M., MacKenzie, S. B., Paine, J. B., \& Bachrach, D. G. (2000). Organizational citizenship behaviors: A critical review of the theoretical and empirical literature and suggestions for future research. Journal of Management, 26(3), 513-563.

Schaufeli, W. B., \& Bakker, A. B. (2003). UWES-Utrecht Work Engagement Scale: Test manual. Utrecht: Department of Psychology, Utrecht University.

Schaufeli, W. B., \& Bakker, A. B. (2004). Job demands, job resources, and their relationship with burnout and engagement: A multi-sample study. Journal of Organizational Behavior, 25, 293-315.

Schaufeli, W. B., Bakker, A. B., \& Salanova, M. (2006). The measurement of work engagement with a short questionnaire. Educational and Psychological Measurement, 66, 701-716.

Schaufeli, W. B., Salanova, M., González-Romá, V., \& Bakker, A. B. (2002). The measurement of engagement and burnout: A two sample confirmatory factor analytic approach. Journal of Happiness Studies, 3, 71-92.

Siemens, E., Roth, A., \& Oliveira, P. (2010). Common method bias in regression models with linear, quadratic, and interaction effects. Organizational Research Methods, 13, 456-476.

Spector, P. E. (2006). Method variance in organizational research: Truth or urban legend? Organizational Research Methods, 9, 221-232.

Stadelmann-Steffen, I., Traunmüller, R., Gundelach, B., \& Freitag, M. (2010). Freiwilligen-Monitor Schweiz, 2010. Zürich: Seismo.

Stegmann, S., van Dick, R., Ullrich, J., Charalambous, J., Menzel, B., Egold, N., et al. (2010). Der Work Design Questionnaire: Vorstellung und erste Validierung einer deutschen Version. Zeitschrift für Arbeits- und Organisationspsychologie, 54, 1-28.

Stukas, A. A., Snyder, M., \& Clary, E. G. (1999). The effects of "mandatory volunteerism" on intentions to volunteer. Psychological Science, 10(1), 59-64.

Vallerand, R. J. (1997). Toward a hierarchical model of intrinsic and extrinsic motivation. In M. P. Zanna (Ed.), Advances in experimental social psychology (Vol. 29, pp. 271-360). San Diego, CA: Academic Press.

Van Beek, I., Hu, Q., Schaufeli, W. B., Taris, T. W., \& Schreurs, B. H. J. (2012). For fun, love or money: What drives workaholic, engaged, and burned-out employees at work? Applied Psychology: An International Review, 61(1), 30-55.

Van den Broeck, A., Vansteenkiste, M., de Witte, H., Soenens, B., \& Lens, W. (2010). Capturing autonomy, competence, and relatedness at work: Construction and initial validation of the workrelated basic need satisfaction scale. Journal of Occupational and Organizational Psychology, 83, 981-1002.

van Schie, S., Güntert, S. T., \& Wehner, T. (2013). How dare to demand this from volunteers! The impact of illegitimate tasks. Voluntas. doi:10.1007/s11266-013-9375-4.

Vecina, M. L., Chacón, F., Sueiro, M., \& Barrón, A. (2012). Volunteer engagement: Does engagement predict the degree of satisfaction among new volunteers and the commitment of those who have been active longer? Applied Psychology: An International Review, 61(1), 130-148.

Williams, L. J., \& Anderson, S. E. (1991). Job satisfaction and organizational commitment as predictors of organizational citizenship and in-role behaviors. Journal of Management, 17(3), 601-617.

Wilson, J. (2012). Volunteerism research: A review essay. Nonprofit and Voluntary Sector Quarterly, 41(2), 176-212.

Wright, B. E., \& Pandey, S. K. (2008). Public service motivation and the assumption of personorganization fit: Testing the mediating effect of value congruence. Administration \& Society, 40(5), $502-521$. 